\title{
Correction to: Theorising Urban Development From the Global South
}

\author{
Anjali Karol Mohan, Sony Pellissery, \\ and Juliana Gómez Aristizábal
}

\section{Correction to:}

A. K. Mohan et al. (eds.), Theorising Urban Development From the Global South, https://doi.org/10.1007/978-3-030-82475-4

The original version of the book was inadvertently published with incorrect author's last name in Chapters 1 and 8. The author's last name is corrected from 'X. M. Abad' to 'X. Méndez Abad'. The book has been updated with the changes.

The updated version of these chapters can be found at https://doi.org/10.1007/978-3-030-82475-4_1 https://doi.org/10.1007/978-3-030-82475-4_8

(C) The Author(s), under exclusive license to Springer Nature $\mathrm{Cl}$ Switzerland AG 2021

A. K. Mohan et al. (eds.), Theorising Urban Development From the Global South, https://doi.org/10.1007/978-3-030-82475-4_12 